Georgetown University Law Center

Scholarship @ GEORGETOWN LAW

2014

\title{
The Difference Prevention Makes: Regulating Preventive Justice
}

David Cole

Georgetown University Law Center, cole@law.georgetown.edu

This paper can be downloaded free of charge from:

https://scholarship.law.georgetown.edu/facpub/1354

http://ssrn.com/abstract=2459976

Crim. L. \& Phil. (March 25, 2014) http://dx.doi.org/10.1007/s11572-013-9289-7

This open-access article is brought to you by the Georgetown Law Library. Posted with permission of the author. Follow this and additional works at: https://scholarship.law.georgetown.edu/facpub

Part of the Constitutional Law Commons, Criminal Law Commons, Immigration Law Commons, Legal History Commons, and the National Security Law Commons 


\title{
The Difference Prevention Makes: Regulating Preventive Justice
}

David Cole

(C) Springer Science+Business Media Dordrecht 2014

\begin{abstract}
Since the terrorist attacks of September 11, 2001, the United States and many other countries have adopted a "paradigm of prevention," employing a range of measures in an attempt to prevent future terrorist attacks. This includes the use of pretextual charges for preventive detention, the expansion of criminal liability to prohibit conduct that precedes terrorism, and expansion of surveillance at home and abroad. Politicians and government officials often speak of prevention as if it is an unqualified good. Everyone wants to prevent the next terrorist attack, after all. And many preventive initiatives, especially where they are not coercive and do not intrude on liberty, are welcome. But the move to a "preventive justice" model also creates potential for significant abuse. These risks suggest that we should be cautious about adopting preventive approaches, especially where they involve coercion. In part I of this essay, I articulate why preventive coercion is a problem. I respond, in particular, to a recent essay by Fred Schauer, "The Ubiquity of Prevention," which argued that "it is a mistake to assume that preventive justice is a problem in itself [because] preventive justice is all around us, and it is hard to imagine a functioning society that could avoid it." In part II, I outline the formal constitutional and other constraints that are implicated by preventive measures in the United States, and I demonstrate that these constraints play a relatively small role in the actual operation of preventive measures. In part III, I maintain that informal constraints may actually play a more significant operational role in checking the abuses of prevention.
\end{abstract}

Keywords Preventive justice $\cdot$ Terrorism $\cdot$ Material support $\cdot$ Preventive detention

Everything did not change on September 11, 2001, but one thing that did, in the United States and elsewhere, was the intensity of the demand to prevent another terrorist attack. By making thinkable what previously seemed unthinkable, the 9/11 attacks unleashed an

D. Cole $(\bowtie)$

Georgetown University Law Center, Washington, DC, USA

e-mail: cole@law.georgetown.edu 
urgent demand for "prevention." One need not insist on preventing the unthinkable, after all; the very fact that it is unthinkable means we need not waste resources trying to stop it. By making such attacks - and worse-much more vivid, real, and immediately threatening, the 9/11 attacks sparked an unprecedented demand for prevention. In the U.S. and elsewhere, government officials charged with keeping their citizens safe responded by prioritizing prevention. As then-Attorney General John Ashcroft announced shortly after the attacks, the United States had entered a "paradigm of prevention." ${ }^{1}$ The paradigm has not shifted since.

In the United States, the paradigm of prevention has had manifold consequences. It has spurred Congress to define crimes of terrorism increasingly expansively, to make it easier to prosecute and convict individuals before they succeed in committing an actual terrorist act. It has led law enforcement officials to charge thousands of loosely defined "suspects" with pretextual offenses, both criminal and immigration-based, in the hope that by doing so some undetected terrorist plot might be averted. It has prompted the aggressive deployment of informants and agents provocateurs in Muslim communities across the country, in an attempt to flush out potential terrorists and incapacitate them before they can act on their nascent tendencies. ${ }^{2}$

The preventive paradigm has also had substantial repercussions outside the criminal and immigration law. As Edward Snowden's revelations about the National Security Agency (NSA) have underscored, ${ }^{3}$ the government has vastly expanded surveillance, at home and abroad, often without meeting the traditional threshold of probable cause that an individual has or is engaged in criminal activity. The preventive paradigm has caused the United Nations Security Council, the United States, and many other nations to impose onerous restrictions on the economic activity of persons and groups labeled as "terrorist" in secret, ex parte government proceedings. It has led the United States to go to war, first in Afghanistan and then in Iraq; to rely on preventive detention and targeted killings; and to expand in unprecedented ways (and ex post facto) the definition of "war crimes" in hopes of holding Al Qaeda suspects criminally responsible in military commissions for acts that were not war crimes when committed. ${ }^{4}$ And perhaps most infamously, the demand for prevention led to the use of cruel and inhumane interrogation tactics against suspected terrorists, up to and including torture, as well as rendition of suspects to other countries so that they could torture them for us.

These are dramatic changes, most immediately felt in Muslim communities, but with ripple effects that extend beyond these targets. The desire for prevention is not limited to terrorism, of course. It is only most strongly felt there. Keeping the citizenry safe by preventing crime is always a governmental priority. New York City's aggressive stop-andfrisk practices, for example, are a preventive measure designed to deter gun violence and other crime on city streets.

\footnotetext{
${ }^{1}$ Prepared Remarks of Attorney General John Ashcroft to the Council on Foreign Affairs, Feb. 10, 2003, available at http://www.justice.gov/archive/ag/speeches/2003/021003agcouncilonforeignrelation.htm.

2 Stephan Salisbury, Mohamed's Ghosts: A Story of Love and Fear in the Homeland (2010); Diala Shamas, Nermeen Arastu, Mapping Muslims: NYPD Spying and Its Impact on American Muslims (2013), available at http://www.law.cuny.edu/academics/clinics/immigration/clear/Mapping-Muslims.pdf.

3 See, e.g., Mirren Gidda, Edward Snowden and the NSA files-timeline, The Guardian (UK), July 25, 2013.

4 See, e.g., Hamdan v. United States, 696 F.3d 1238 (D.C. Cir. 2012) (reversing war crime conviction for "material support" of terrorism on the ground that "material support" was not a war crime recognized by international law at the time of charged conduct of alleged driver and bodyguard for Osama bin Laden).
} 
Prevention can take many forms. Some preventive measures raise few if any constitutional or ethical concerns. Target-hardening of cockpit doors, for example, is a preventive measure, as are better lighting of urban alleys or more adult-supervised afterschool programs for youth. The preventive measures that raise concern, however, are those that bring the coercive force of the law to bear on individuals and groups. It is this preventive coercion that will be the focus of this essay.

In part I, I articulate why preventive coercion is a problem. This part responds, in particular, to a recent essay by Fred Schauer, "The Ubiquity of Prevention," which argued that "it is a mistake to assume that preventive justice is a problem in itself [because] preventive justice is all around us, and it is hard to imagine a functioning society that could avoid it." In part II, I outline the formal constitutional and statutory constraints that are implicated by preventive measures in the United States, but I also demonstrate that these constraints play a relatively small role in the actual operation of preventive measures. In part III, I maintain that for a variety of reasons, informal constraints may play a more significant operational role in checking the abuses of prevention.

\section{The Difference Prevention Makes}

In "The Ubiquity of Prevention," Fred Schauer argues that "preventive justice" does not pose distinct normative concerns, because prevention is everpresent in the criminal justice system. Schauer is correct that prevention as a motive and justification has long been ubiquitous in criminal law and its enforcement, so that there is more continuity between pre- and post-9/11 approaches than is sometimes acknowledged. One of the aims of criminal law enforcement has always been the prevention of crime. When we impose a sentence of incarceration, we incapacitate the defendant, and hope to deter others-both preventive ends. But Schauer is wrong, I believe, to maintain that prevention does not raise particular problems. The preventive use of coercion raises distinct normative concerns from punitive uses of coercion-even if some or even most punitive measures also have preventive goals. Because of the ubiquity of prevention in post-9/11 security policy, it is important to identify those distinct concerns carefully.

The difference that prevention makes can be seen first-hand in the United States, where the post-9/11 full-scale adoption of a paradigm of prevention amounted to a sea change in law enforcement. In particular, the United States has dramatically increased its use of targeted coercive sanctions against individuals, not primarily for what they have done in the past, but for what it fears they might do in the future. It is one thing to note that ordinary enforcement of criminal sanctions against past acts has deterrent and incapacitative effects that serve preventive purposes. It is another matter entirely, however, to impose targeted sanctions on individuals not for their past acts, but to prevent them from engaging in future bad acts.

Schauer resists the difference, noting that traditional penalties based on past acts, like sanctions predicated on future dangers, depend on proof that is ultimately probabilistic, and therefore inescapably involves some risk of error. We can rarely know with 100 percent certainty that a defendant committed the past act with which he is criminally charged, Schauer argues, and a conviction does not require such perfect certainty, but only proof beyond a reasonable doubt. Thus, he argues, convictions for past crime, like coercion

\footnotetext{
5 Fred Schauer, "The Ubiquity of Prevention," in Andrew Ashworth, Lucia Zedner, \& Patrick Tomlin, eds., Prevention and the Limits of the Criminal Law (Oxford University Press, 2013), 10-22.
} 
imposed for preventive ends, inevitably involve some risk of error. This much is true. But Schauer's effort to collapse the distinction between future-oriented prevention and pastdirected punishment ultimately fails. The concerns and risks raised by the targeted imposition of coercive sanctions on individuals for preventive ends are different, in substantial degree, and sometimes in kind, from those raised by criminalizing and punishing past acts, for five reasons.

First, and most importantly, however difficult it may be under some circumstances to determine who did what in the past, it is not just difficult, but impossible, to predict with anything like an equivalent degree of certainty what an individual will do in the future, at least where free will is involved. (We can predict with confidence, for example, that a given person will breathe in the future, but we generally cannot predict with such confidence that he will choose to go to a particular restaurant, or commit a particular crime.) The impossibility of predicting the future means that when we impose sanctions based on future concerns rather than past acts, we inevitably must accept a lower standard of proof, and far greater risk of error, than when we impose sanctions for past acts. Criminal sanctions for past acts require proof beyond a reasonable doubt. If preventive sanctions could be imposed only when we know beyond a reasonable doubt that an individual will commit an illegal act in the future, such sanctions would almost never be imposed. Yet proof beyond a reasonable doubt is precisely what we require-and what prosecutors routinely satisfy - in traditional criminal trials. While proof of past acts and future acts are both probabilistic, there are inherent limits on our ability to know the future that make prediction of future conduct much more fraught than assessment of past conduct. Thus, while it might be possible to insist on 90 or 95 percent certainty of past conduct for a conviction, it is simply not possible to insist on the same degree of certainty with respect to the future. Once we cross the threshold of imposing penalties and sanctions for what someone might do in the future, we must necessarily also reduce the degree of certainty we demand-and therefore, increase the risk of error.

Second, punishing an individual for past acts voluntarily or intentionally undertaken does not disrespect her autonomy and free will. The criminal law acknowledges that people have choices to make, and holds them responsible when they make choices that the community has determined are socially disruptive. Holding an individual responsible for her choices, as long as they are choices, respects her autonomy and free will. Indeed, if we did not believe that a defendant had free will, it would not be fair to punish her. For this reason, it is not permissible to make the status of being addicted to drugs a crime. ${ }^{6}$ Thus, the traditional criminal sanction affirms free will. Punishing or otherwise restricting an individual's liberty based on a prediction that she might do something bad in the future, by contrast, disrespects her free will, by dismissing or disregarding her ability to choose to conform her actions to society's norms.

Third, when the state imposes sanctions for what an individual might do in the future, rather than for what she did in the past, the dangers of selective prosecution based on impermissible criteria of race, ethnicity, or sex, are especially pronounced. While selective enforcement is of course a potential problem in the investigation and prosecution of past crimes, the problem is likely to be exacerbated when the state engages in predictive policing. Virtually by necessity, predicting what an individual might do in the future necessitates judgments based on generalizations about the kind of person he is. There is a real risk that in making such judgments we will rely on group-based generalizations that violate principles of equal treatment. Seeking to prevent espionage and sabotage, President

${ }^{6}$ Robinson v. California, 370 U.S. 660 (1962). 
Franklin Delano Roosevelt ordered the internment of all persons of Japanese descent on the West Coast during World War II. Similarly, police in New York City stopped and frisked black and Hispanic young men more frequently than whites, presumably based on their assumption that such men were more likely to be carrying guns or drugs, or otherwise to pose a risk of future criminal activity. ${ }^{7}$ In assessing responsibility for past actions, there is an especially strong norm that people must be judged by their acts, not their status; but when one turns to prediction, and the acts have yet to take place, generalizations are virtually inescapable. And as history has shown, race, ethnicity and sex-based stereotypes often have a strong pull on our expectations and judgments about people.

The second and third concerns identified above are mutually reinforcing. The centrality of autonomy to notions of human agency makes its denial easier with respect to those viewed as "other," or different from ourselves. At the same time, the denial of autonomy is particularly pernicious when focused on members of groups already more likely to be viewed as "other." The denial of autonomy eases the discrimination, and the discrimination in turn makes it easier to deny or disregard the autonomy of those we see as different from us.

Fourth, a focus on preventing future harms affords no natural check on enforcement measures. If we criminalize murder, and there are no murders, there are unlikely to be any prosecutions for murder. If we adopt measures designed to prevent murders in the future, we never can know whether our initiatives have in fact prevented murders that would have happened, or whether the murders would not have occurred even if we had done nothing. There have been virtually no terrorist attacks in the United States in the twelve years since $9 / 11$, but is that because of, or in spite of, our preventive measures? Could we have achieved the same result with less aggressive preventive measures? We do not, and probably can never know. In the face of this uncertainty, "better safe than sorry" leads almost inevitably to overinvestment in prevention in times of fear. We are currently spending approximately $\$ 80$ billion on counterterrorism initiatives - not counting Iraq and Afghanistan expenditures - to stop an estimated 4,000 persons thought to be members of Al Qaeda and associated forces from launching terrorist attacks against us. That's \$20 million per suspected terrorist per year. ${ }^{8}$

The requirement that sanctions must be predicated on for past acts is not always a check on overzealous enforcement, particularly where the criminal conduct is widespread, as the war on drugs in the United States has demonstrated. But with more serious and less frequent crimes, one can generally prosecute only acts that have occurred. No such limit applies to prevention, as one can never know what acts have-or have not-been prevented. Thus, no objective measure exists by which one can reliably know how much is too little, too much, or just enough prevention. When fear is pervasive, this uncertainty breeds overenforcement.

Fifth, and finally, it is not just that we cannot know the efficacy of prevention; our assessments are likely to be systematically skewed. The nature of prevention is such that there is an inevitable imbalance between false negatives - where we wrongly conclude that an individual poses no terrorist threat, and he goes on to commit a terrorist threat-and false positives-where we wrongly conclude that an individual poses a terrorist threat but

\footnotetext{
7 Floyd v. City of New York, 2013 U.S. Dist. LEXIS 113271 (S.D.N.Y. Aug. 12, 2013).

8 Dan Raviv, Funding for fighting Al Qaeda could be cut, ex-spy chief says, CBS News, Oct. 28, 2011, available at http://www.cbsnews.com/8301-503544_162-20126972-503544/funding-for-fighting-al-qaedacould-be-cut-ex-spy-chief-says/; David Cole, After September 11: What We Still Don't Know, N.Y. Rev. of Books, Sept. 29, 2011.
} 
he is in fact innocuous. If we err on the side of assuming an individual does not warrant preventive measures, and he commits a terrorist act, the error is vivid and visible - think of Willie Horton. If, by contrast, we err on the side of caution and unnecessarily impose preventive measures on an individual who would have done no harm had we left him alone, the "false positive" error is invisible, and ultimately unknowable. Anyone confronting such an imbalance is likely to err on the side of caution, thus leading to a high incidence of false positives. This dynamic produces overly aggressive enforcement (see New York's stop-and-frisk campaign), overly aggressive detention and pretextual prosecution (see the detention of over 5,000 foreign nationals, nearly all Muslim, in the U.S. in the first two years after 9/11, none of whom turned out to be convicted of terrorism), and overly aggressive inducements to commit terrorist acts by informants and provocateurs. ${ }^{9}$

For these reasons, preventive coercion raises concerns that are distinct from the concerns posed by holding people accountable for past wrongs. These concerns in turn implicate important constitutional and nonconstitutional legal principles. In the following section, I will describe those principles and their application to preventive coercion.

\section{The Limits of Law}

Notwithstanding all of the above bases for concern, the Constitution does not prohibit prevention as a tactic or a motive, and for good reason. We want our government to prevent crime, and as noted above, there are many situations in which prevention infringes few or no rights. Preventive coercion raises more substantial concerns, but is also sometimes justified, as in a quarantine to halt the spread of a deadly communicable disease, a protective order designed to forestall domestic abuse, or the detention pending trial of a defendant who poses a risk of flight or danger to others. Incarceration as punishment for the commission of serious criminal offenses is often motivated in part by preventive concerns and has preventive effects. Thus, there is no absolute prohibition on prevention, nor should there be.

In theory, the paradigm of prevention is constrained by a number of constitutional principles under U.S. law, including substantive and procedural due process, freedoms of speech and association, equal protection, and the civil-criminal divide. In practice, however, formal constitutional constraints have played a relatively modest role in restricting preventive measures. In part because prevention is as ubiquitous as Schauer notes, and virtually impossible to disentangle cleanly from other criminal justice goals, constitutional doctrine has developed few bright lines. But that is not to say that there are no limits. On occasion, courts have ruled certain preventive measures unconstitutional. Perhaps because the limits are well accepted, most of the controversy today in preventive coercion takes place within the boundaries marked out by constitutional rules, and is the subject of less formal, more political constraints.

\section{A. The Principal Legal Constraints on Prevention}

There are multiple legal constraints on prevention under U.S. law. First, the First and Fifth Amendments restrict the state's ability to target speech and association. Governments have often used speech and association as proxies for who might engage in future dangerous conduct, and penalized speech or association as a way of preempting that conduct. In the

\footnotetext{
${ }^{9}$ See Trevor Aaronson, The Terror Factory: Inside the FBI's Manufactured War on Terrorism, (2013).
} 
anti-Communist era, for example, federal law made both advocacy of Communist doctrine and membership in the Communist Party crimes. After initially tolerating such laws, the Supreme Court ultimately ruled that membership may not be prohibited absent proof that an individual specifically intends to further the party's illegal ends, ${ }^{10}$ and that advocacy of violent overthrow of the government (or of any other criminal activity) may not be punished unless the speech is both intended and likely to incite imminent lawless action. ${ }^{11}$ These rules, which remain good law to this day, reflect lessons learned from the McCarthy era, in which thousands of innocent citizens were caught up in the preventive frenzy of anti-communism. $^{12}$

Second, the due process clause imposes both substantive and procedural limits on the use of detention as a preventive measure. The most important substantive limit is that preventive detention can be employed only when the criminal justice system is inadequate to address socially dangerous conduct. ${ }^{13}$ The Supreme Court has ruled that the state may not subject individuals to indefinite preventive detention on the basis of future dangerousness alone. ${ }^{14}$ We presume that people will conform their actions to criminal laws, and generally subject them to detention only upon proving that they failed to do so in the past, not based on predictions that they will fail to do so in the future. Civil commitment, an exception to this rule, is permissible only where an individual is found both to be dangerous and to have a mental disability that undermines his ability to control himself. ${ }^{15}$ This approach reflects a presumption that criminal sentences for past acts are the appropriate route for addressing and preventing dangerous conduct. The requirement of a mental disability that undermines the individual's ability to conform his actions to the criminal law permits civil commitment as a general matter only where we are unlikely to be able to hold him criminally culpable, because he cannot control his actions. ${ }^{16}$

In the bail setting, the Supreme Court has permitted limited preventive detention pending trial of persons who pose a future danger but are not mentally ill. But here, too, the result is consistent with the notion that preventive detention is permissible only where enforcement of the criminal law against past acts cannot adequately address the danger presented. In United States v. Salerno, ${ }^{17}$ the Court upheld the Bail Reform Act, which permits denial of bail to defendants charged with particularly serious crimes, where the state shows that they would pose a risk of danger to the community if freed on bail, and that there are no less restrictive means available to protect the community. In upholding this use of preventive detention, the Court stressed that it applied only to those charged with serious crimes, that the length of detention was limited by the requirement of a speedy

${ }^{10}$ U.S. v. Scales, 367 U.S. 203 (1961).

11 Brandenburg v. Ohio, 395 U.S. 444 (1969).

12 See, e.g., Geoffrey Stone, Perilous Times. Free Speech in Wartime from the Sedition Act of 1798 to the War on Terrorism 311-426 (2004).

13 David Cole, Out of the Shadows: Preventive Detention, Suspected Terrorists, and War, 97 Cal. L. Rev. 693 (2009).

14 Foucha v. Louisiana, 504 U.S. 71 (1992).

15 Kansas v. Hendricks, 521 U.S. 346 (1997); Kansas v. Crane, 534 U.S. 407 (2002); Eric S. Janus and Wayne A. Logan, Substantive Due Process and the Involuntary Confinement of Sexually Violent Predators, 35 Conn. L. Rev. 319 (2003).

16 Stephen Schulhofer, Two Systems of Social Protection: Comments on the Civil-Criminal Distinction, with Particular Reference to Sexually Violent Predator Laws, 7 J. Contemp. Legal Issues 69 (1996); Cole, Out of the Shadows supra note 13.

17481 U.S. 739 (1987). 
trial, and that the state was required in each case to show that no less restrictive measures would suffice to protect the community. Here, too, preventive detention fills a gap in criminal justice. We cannot immediately incarcerate individuals for criminal activity, as trials take time to prepare and conduct. Accordingly, where necessary to protect the community, it is permissible to detain certain criminal defendants pending trial. (The same principle applies to the detention of immigrants pending deportation who pose a risk of flight or danger to the community).

A similar due process principle governs quarantines to stem the spread of dangerous and highly communicable diseases. This practice is entirely preventive in character. Quarantines are permissible because the danger of disease transmission cannot be addressed through the criminal justice approach of holding people responsible for culpable behavior. One cannot be held criminally responsible for being sick. Accordingly, the quarantine responds to a social danger where the criminal justice system cannot.

The same substantive due process principle helps to explain preventive detention during wartime. ${ }^{18}$ In a war, those fighting generally have the "privilege of belligerency" as long as they abide by minimal rules of conduct. This privilege means that the state cannot criminally punish those fighting against it for murder and assault, which would of course otherwise be prosecutable crimes. Because such conduct cannot be addressed through criminal law, preventive detention is permitted for the course of the conflict-but no longer. Once the conflict ends, the privilege of belligerency is lifted, and the state can - and must-revert to criminal law enforcement if it seeks to detain those who allegedly pose a danger to the community.

Procedural due process also imposes checks on preventive coercion. If the state seeks to take an individual's liberty or property, it must generally ensure that he has notice of the basis for its action and a meaningful opportunity to defend himself. This principle has been held to apply to the preventive freezing of property of alleged terrorists and supporters of terrorism $^{19}$; the preventive detention of U.S. citizens allegedly fighting for the enemy during wartime ${ }^{20}$; and the civil forfeiture of property used for criminal purposes. ${ }^{21}$

Third, a significant limit on prevention is reflected in the rule that the government may not impose punishment without the procedural safeguards associated with criminal trials, as set forth in the Fifth and Sixth Amendments. ${ }^{22}$ To determine whether a preventive measure is punitive, the Court employs a multi-factor test that examines: whether it imposes a disability; whether that kind of disability has historically been viewed as punishment; whether it requires a finding of scienter; whether its imposition serves the traditional aims of punishment; whether the behavior that triggers it is already a crime; whether an alternative purpose exists; and whether it is excessive in relation to the

\footnotetext{
${ }^{18}$ See Cole, Out of the Shadows, supra note 13 at 706-718.

19 Al Haramain Islamic Found, Inc. v. United States Dep't of the Treasury, 686 F.3d 965 (9th Cir. 2012); KindHearts for Charitable Humanitarian Dev., Inc. v. Geithner, 710 F. Supp. 2d 637 (N.D. Ohio 2010). I was counsel for plaintiffs in both of these cases.

${ }^{20}$ Hamdi v. Rumsfeld, 542 U.S. 507 (2004).

21 United States v. James Daniel Good Real Prop., 510 U.S. 43 (1993).

22 Kennedy v. Mendoza-Martinez, 372 U.S. 144, 165-166 (1963) (holding that stripping draft evaders of citizenship was punishment that could not be imposed without the safeguards of a criminal trial); see also, Eric Sandberg-Zakian, Counterrorism, the Constitution, and the Civil-Criminal Divide: Evaluating the Designation of U.S. Persons under the International Emergency Economic Powers Act, 48 Harv. J. on Legis. 95 (2011).
} 
alternative purpose. ${ }^{23}$ If a sanction is deemed punitive, it may not be imposed without all the constitutional safeguards that accompany criminal prosecution (including the requirement of proof beyond a reasonable doubt of a clearly defined crime).

Fourth, preventive measures may implicate equal protection concerns. As noted above, preventive predictions are often predicated on group characteristics. Where predictions are based on characteristics that trigger skeptical treatment under the Constitution, such as race, sex, or ethnicity, the Equal Protection Clause may prohibit the state's action. Thus, an official decision to stop and search black and Hispanic drivers more often than white drivers, on the prediction that black and Hispanic drivers are more likely to be transporting drugs, is likely to violate the Equal Protection Clause. To establish an equal protection violation, one must prove that the state acted because of race, ethnicity or sex, and that it treated similarly situated others differently, both of which can be difficult to prove. ${ }^{24}$ Nonetheless, the principle that the state may not rely on race-, sex-, or ethnicity-based generalizations imposes some check on preventive measures.

Fifth, and finally, the entrapment doctrine provides both a constitutional and a nonconstitutional limit on preventive measures. One technique for preempting and preventing crimes is the "sting" operation, in which informants or undercover agents identify individuals who they suspect may be inclined to commit crimes, and then tempt them into committing a crime with various forms of encouragement and assistance. Since $9 / 11$, the United States has successfully prosecuted many individuals for attempted terrorist crimes in this way. ${ }^{25}$ The entrapment doctrine provides a theoretical limit on such tactics. If the state is unable to show that an individual who responded to an enticement to commit a crime was "predisposed" to commit that crime, the defense of entrapment will bar conviction. ${ }^{26}$ In addition, if the government seeks to encourage criminal conduct through measures that are "shocking to the universal sense of justice," the due process clause may preclude conviction. ${ }^{27}$ The idea is that there must be some point beyond which the state may not "stress-test" its citizens by tempting them to commit crimes they would not otherwise have committed.

All of these principles limit the state's preventive choices in important ways. It cannot criminalize pure speech or membership absent proof of a close nexus to illegal conduct. It cannot lock up citizens for preventive purposes except where the presumptive route of criminal law enforcement is unavailable. It cannot impose punitive sanctions without the full safeguards of the criminal process. Even if sanctions are deemed nonpunitive, if they restrict liberty or property, they must be accompanied by due process. The state may not single out targets for prevention based on generalizations about their race, sex, or ethnicity. And if the state entraps people who are not predisposed to commit a crime, prosecution will be barred. These doctrines limit the coercive tactics the state can adopt for preventive purposes, and thereby mitigate some of the risks presented by preventive measures. None of these principles is a panacea for the dangers of prevention delineated in part I, to be sure, but robustly enforced, they provide significant safeguards.

\footnotetext{
${ }^{23}$ Kennedy v. Mendoza-Martinez, 372 U.S. at 168-169.

24 United States v. Armstrong, 517 U.S. 456 (1996); McCleskey v. Kemp, 481 U.S. 279 (1987).

25 Aaronson, The Terror Factor, supra note 9.

26 Jacobson v. United States, 503 U.S. 540 (1992).

27 United States v. Russell, 411 U.S 423, 432 (1973), quoting Kinsella v. United States ex rel. Singleton, 361 U.S. 234, 246 (1960).
} 


\section{B. The Limits of the Legal Constraints}

At the same time, each of the doctrinal constraints outlined above is limited in significant ways, as post-9/11 developments have starkly illustrated. When the demand for prevention is strong, it will find ways to make itself manifest, and in practice these doctrines may prove inadequate to guard against abuse. For example, while the First Amendment prohibitions on penalizing speech and association remain intact, Congress has made it a crime to provide "material support" to disfavored foreign groups, and has defined support expansively to include speech, such as "expert advice" or "training," regardless of whether it advocates or furthers terrorism in any way. ${ }^{28}$ Hundreds have been prosecuted under the law, and in Holder v. Humanitarian Law Project, the Supreme Court ruled that this law is constitutional even as applied to speech advocating only human rights and peace, and neither intended nor likely to further any illegal activity. ${ }^{29}$ The Court claimed to be applying heightened scrutiny to the law's prohibitions on speech, a standard that generally requires the government to show that penalizing speech is the least restrictive means to further a compelling state interest. The government did not even argue, much less demonstrate, that penalizing advocacy of peace and human rights was the least restrictive means to further the end of fighting terrorism, but the Court nonetheless upheld the law. It reasoned that given the law's future-oriented preventive goals, the Court could not require the government to show that the restrictions were necessary. ${ }^{30}$ Thus, the law's preventive character effectively reduced the level of scrutiny the government had to satisfy in order to penalize speech because of its content.

In the same case, the Court also rejected the plaintiffs' contention, resting on the Communist Party cases, that penalizing support to a group without proof of intent to further its illegal ends impermissibly imposed guilt by association in violation of the First and Fifth Amendments. The Court reasoned that the law did not criminalize membership itself, but only material support. ${ }^{31}$ On this reasoning, Congress could have continued to penalize association with the Communist Party by criminalizing not membership itself, but the provision of any assistance or support to the group. The right of association is a meaningless formality if one is not free to do anything to support the group with which one has a right to associate. What would the right to associate with the Democratic Party or the National Rifle Association mean, for example, if the government could make it a crime to pay dues to, speak on behalf of, or volunteer one's time to the organization? Thus, while it remains true that the government may not pursue preventive ends by directly penalizing speech or association, Humanitarian Law Project suggests that it may achieve the same ends by prohibiting any speech or association in connection with the group as "material support." 32

The substantive due process restraints on preventive detention are also less robust than first appears. While the Court has foreclosed indefinite preventive detention on the basis of

\footnotetext{
2818 U.S.C. 2339 B.

29 Holder v. Humanitarian Law Project, 130 S. Ct. 2705 (2010). I was counsel to Humanitarian Law Project in this case.

${ }^{30}$ For detailed critiques of the Court's analysis, see David Cole, The First Amendment's Borders: The Place of Holder v. Humanitarian Law Project in First Amendment Doctrine, 6 Harv. L. \& Pol'y Rev. 147 (2012); Owen Fiss, The World We Live In, 83 Temp. L. Rev. 295 (2011).

31 Humanitarian Law Project, 130 S. Ct. at 2730-31.

32 The First Amendment holding in Humanitarian Law Project may be limited to support to foreign organizations, as the Ninth Circuit recently implied in a case striking down restrictions on speech provided as support to a domestic group labeled as terrorist. Al Haramain Islamic Fdn v. U.S. Dept of Treasury, 686 F.3d at 995-1001; Cole, The First Amendment's Borders, supra note 30.
} 
mere dangerousness, and has required some showing of mental disability, some have criticized that process on the ground that it outsources the detention decision to medical professionals, applying loose and vague standards that courts cannot meaningfully oversee. ${ }^{33}$ And because of the skewed incentives in favor of false positives, it is likely that many persons are civilly committed who would not in fact cause harm if released.

Procedural due process, too, is a less than watertight protection against preventive abuse. The Supreme Court has long determined what process is due by balancing individual interests against government interests, taking into account the risks of error. ${ }^{34}$ While the Court has suggested that, at a minimum, procedural due process requires notice and a meaningful opportunity to respond to the government's case, ${ }^{35}$ what that means in practice is not always crystal-clear. Thus, the Court held that indefinite wartime preventive detention of a U.S. citizen said to be fighting alongside the enemy could be based on hearsay, and could be supported by a presumption in favor of the government-effectively shifting the burden to the detainee to prove his innocence. ${ }^{36}$ And in the context of asset freezes and terrorist designations, some courts have ruled that the government may rely on secret evidence, need only disclose to the designated entity or person any unclassified evidence it is relying upon (but not the classified evidence), and may limit the opportunity to respond to a written submission. ${ }^{37}$

The prohibition on imposing punitive sanctions without criminal trial often begs the question of what constitutes a punitive sanction. The Court's application of the multi-factor test articulated above for identifying punitive sanctions has been anything but consistent. As Wayne Logan has put it: "Despite [the subject's] importance, the Court's numerous decisions in the area have amounted to an incoherent muddle. Indeed, one would be hardpressed to identify an area of constitutional law that betrays a greater conceptual incoherence." ${ }^{38}$ In part, this is because it is not possible to draw a clear line demarcating the civil from the criminal, and many sanctions that have punitive effects can be defended by the state as serving some other purpose. In particular, in the preventive context, the state will almost always claim that its purpose is not to punish but to prevent. If the civilcriminal divide is going to do any work in setting limits on preventive sanctions, the Court must be willing to look behind such blanket assertions, as indeed its multi-factor test invites it to do, by assessing whether the sanction is proportional to the nonpunitive interest asserted. But given the difficulty of measuring future risk and the effectiveness of preventive measures, courts will rarely find sanctions disproportionate.

Equal protection doctrine also provides only limited protection, because the Court has long held that proof of intentional discrimination is required to make out an equal protection claim under the Constitution. Racial profiling is often difficult to prove, because officials rarely admit that they rely on racial generalizations, even where the statistical

\footnotetext{
33 See, e.g., Eric Janus, Preventive Detention of Sex Offenders: The American Experience Versus International Human Rights Norms, 31 Behavioral Sciences and the Law 328 (2013).

34 Matthews v. Eldridge, 424 U.S. 219 (1976).

35 Hamdi v. Rumsfeld, 542 U.S. 507.

${ }^{36}$ Hamdi v. Rumsfeld, 542 U.S. at 533-34.

37 Nat'l Council of Resistance of Iran v. Dep't of State, 251 F.3d 192 (D.C. Cir. 2001). Other courts have required more robust process, including notice of the basis for the designation, and where feasible, an unclassified summary of any classified evidence relied upon, and the provision of access to the classified evidence to counsel with security clearances. Al Haramain Islamic Found., 686 F.3d at 982-988.

38 Wayne A. Logan, The Ex Post Facto Clause and the Jurisprudence of Punishment, 35 Am. Crim. L. Rev. 1261, 1268 (1998).
} 
evidence is overwhelming. Statistical showings of disparate impact may in some circumstances support an inference of intentional discrimination, but unless a court concludes that intentional discrimination has been proven, no equal protection violation will be found. ${ }^{39}$ As a result, few defendants have ever prevailed on a selective prosecution claim.

The entrapment defense also often proves illusory, particularly in cases alleging serious crimes. The mere fact that a defendant has agreed to commit a criminal offense as serious as terrorism is generally enough to support an inference that he was predisposed to commit the offense. Given the profound opprobrium associated with serious crime, a juror is likely to be very skeptical that anyone not predisposed to engage in such conduct would agree to commit the crime in question, almost without regard to the nature of the inducement. While entrapment defenses sometimes succeed in prosecutions for relatively minor crimes, such as drugs or pornography, they almost never succeed against more serious charges. No defendant in a terrorism case has successfully mounted an entrapment defense, despite very aggressive encouragement by informants. ${ }^{40}$ The defense might be available were the government to go to truly extraordinary lengths in encouraging a reluctant individual to undertake a relatively modest terrorist crime, such as the provision of otherwise innocuous material support. But for the most part, the cases since 9/11 in which the government has prosecuted individuals for terrorist crimes that they were encouraged to undertake involve the provision of military-type support, such as missiles, or actual attempted terrorist acts, such as attempting to detonate a bomb.

Other preventive measures confront no constitutional or legal barriers at all. Thus, the Constitution imposes no obstacle to the common preventive practice of pretextual prosecution, in which the government identifies an individual suspected of engaging in or planning to engage in serious crime, for which it lacks sufficient evidence to convict, and prosecutes him instead for some other relatively minor offense in order to "disrupt" the more serious crime. U.S. Attorney General John Ashcroft proudly announced that this tactic would be used after 9/11, and thousands of persons "of interest" to the $9 / 11$ investigation were rounded up, mostly on immigration charges, and eventually deported, in an effort to prevent a follow-on attack. (None of over 5,000 foreign nationals detained in the first two years after 9/11 in anti-terrorism initiatives was ultimately convicted of a terrorist offense, though many were deported for minor immigration infractions.)

Pretextual stops, a less intrusive but far more common preventive law enforcement practice, also face few constitutional obstacles. In Whren $v$. United States, ${ }^{41}$ the Supreme Court upheld the practice of pretextual traffic stops-in which police officers stop drivers for traffic infractions in hopes of discovering some other crime, usually drug possession or trafficking. The traffic laws are so extensive that it is said the police can stop virtually anyone in an automobile simply by following them for ten minutes. It is no coincidence that so many accounts of "racial profiling" involve traffic stops. As the post-9/11 roundups demonstrated, immigration law provides a similarly rich opportunity for pretextual arrests of foreign nationals, because its regulations and requirements are so byzantine and extensive. $^{42}$

Recent controversies over aggressive "stop-and-frisk" practices in New York City, disproportionately targeted at black and Hispanic young men, illustrate that pedestrians can

\footnotetext{
39 McCleskey v. Kemp, 481 U.S. 279.

40 See Aaronson, The Terror Factory, supra note 9.

41 Whren v. United States, 517 U.S. 806 (1996).

42 See David Cole, Driving While Immigrant, The Nation, May 12, 2003.
} 
also be subjected to pretextual preventive coercive measures without much constitutional constraint. The Supreme Court has ruled that a temporary stop is permissible only where the police have "reasonable suspicion," based on objective facts, that crime is afoot, and that a frisk or pat-down of the outer clothing is permissible only where the police also have "reasonable suspicion" that the individual is armed. ${ }^{43}$ However, the vast majority of such encounters do not lead to a criminal prosecution, and as a result, trigger no court supervision. In New York City, for example, in 2011, only two percent of stops and frisks found contraband of any kind. ${ }^{44}$ It is generally not worth it for any one individual to sue civilly for such an encounter, as the damages are likely to be minimal even if the plaintiff establishes liability. Recent class action lawsuits in New York and Philadelphia have underscored the extent to which such stops and frisks are often conducted without the constitutionally required reasonable suspicion, but it remains to be seen whether effective remedies will be developed.

Thus, while the Constitution and entrapment law impose some important outer boundaries on coercive preventive measures, the government retains substantial discretion within those boundaries to engage in preventive coercion. Constitutional doctrine forecloses the most extreme preventive measures-detention for dangerousness alone, criminalization of speech and association, punishment without trial, explicit racial profiling, and truly outrageous efforts at entrapment. But the government can avoid those extremes and still engage in a broad range of targeted, coercive preventive measures, most of which still implicate the normative concerns identified in Part I above. At the end of the day, the most significant checks on prevention are likely to be more political than legal. This is not to say that the constitutional constraints detailed above are unimportant, but only that most of the "action" occurs within the outer boundaries of those formal constraints.

\section{Informal Checks}

If constitutional and other formal legal checks play only a limited role in the actual give and take of preventive measures, are there alternative sources of constraint? What are they, and how are they triggered? What can be done to ensure that preventive coercive measures avoid the normative concerns identified above?

\section{A. Community Response and Legitimacy}

Perhaps the most important source of limitation on preventive justice as it is practiced today is community reaction. One of the most valuable tools in preventing crime is good community relations. If the community trusts the police, its members are more likely to cooperate in investigations by offering testimony or leads. No one is more likely to know where trouble lies than those living in the relevant community. Their "eyes and ears" are critical to effective ferreting out of potential criminals before they commit their worst crimes, as well as to bringing perpetrators to justice for past crimes.

Community trust may affect the level of crime even more directly. Studies show that one of the most influential forces determining whether people obey the law is its perceived

\footnotetext{
43 Terry v. Ohio, 392 U.S. 1 (1968).

44 Center for Constitutional Rights, 2011 NYPD Stop-and-Frisk Statistics, available at http://ccrjustice.org/ files/CCR-Stop-and-Frisk-Fact-Sheet-2011.pdf.
} 
legitimacy. ${ }^{45}$ If the community views coercive preventive measures targeted at their members as unfair or unjust, they may ultimately prove self-defeating.

The police know this. Federal and local law enforcement officials after 9/11, for example, initiated a series of "councils" with members of the Arab and Muslim communities in several cities, including Chicago, Detroit, and Los Angeles. Through regular meetings with community leaders, they sought to foster trust and open lines of communication, in large part so that if community members identified a potential terrorist in their midst, they would be inclined to contact law enforcement officials in time to prevent a terrorist act. This effort was also likely designed to offset the resentment that might be triggered when many preventive law enforcement measures were targeted at Arab and Muslim communities. Even though that targeting might not be vulnerable to a successful equal protection challenge, for the reasons discussed above, law enforcement officials were nonetheless sensitive to the appearance of unfairness that it was likely to generate, and sought to assuage those concerns by working with and listening to community leaders.

Similarly, police initiatives designed to prevent gun violence and close open-air drug markets often include as an essential element the involvement of the community. In his recent book, Don't Shoot, David Kennedy advocates that police seeking to reduce gun violence in the inner city, for example, engage the community in order both to help identify the small number of individuals who are responsible for most of the violence, and to offer assistance to those who agree to change course and forswear violence for more law-abiding ways. ${ }^{46}$ The initiatives, which require the affirmative involvement of the community, appear to have been successful in multiple cities, coinciding with dramatic drops in gun violence.

The constitutional and normative concerns delineated above play an important role here, even if they do not often lead to formal judicial checks. Perceptions of legitimacy are shaped by normative constitutional concerns. The question for the state therefore is not simply whether preventive measures can withstand a lawsuit, but whether the community will view them as legitimate. The police need legitimacy, and legitimacy demands fidelity to the spirit of constitutional concerns, not just the avoidance of courtroom defeats.

If the state implements overly aggressive preventive measures that appear to be sweeping up the innocent, running roughshod over procedural safeguards, imposing undue burdens on community members, or unfairly treating one group of persons differently than others, the measures may well jeopardize prevention by undermining community relations and the perceived legitimacy of law enforcement. In this sense, there ought to be a selfcorrecting mechanism; as police see the alienating and counterproductive effects of their more problematic preventive initiatives, they should have an incentive to roll them back. In New York City, for example, the police, perhaps in response to a slew of negative publicity about the "stop-and-frisk" program, dramatically reduced the number of people subjected to the practice-even before a court ruled their practices unconstitutional. ${ }^{47}$

However, this corrective mechanism is not automatic; in fact, it is unlikely to work well at all without significant effort. There are too many barriers to information; both sides of

\footnotetext{
45 Tom R. Tyler, Why People Obey the Law (2006); Tom R. Tyler, Stephen Schulhofer, and Aziz Z. Huq, Legitimacy and Deterrence Effects in Counterterrorism Policing: A Study of Muslim Americans, 44 Law \& Soc. Rev. 365 (2010).

${ }^{46}$ David M. Kennedy, Don't Shoot: One Man, a Street Fellowship, and the End of Violence in Inner-City America (2012). For a more detailed analysis of Kennedy's project, see David Cole, Our Romance With Guns, N.Y. Rev. of Books, Sept. 27, 2012.

47 Tamer El-Ghobashy and Michael Howard Saul, New York Police Use of Stop-and-Frisk Drops, Wall St. J., May 6, 2013.
} 
the relationship may labor under preconceptions and distrust that interfere with effective communication. The police may not know the community well; community members may lack the wherewithal to express their views effectively. At one workshop I attended on police-citizen councils in Muslim communities, an FBI agent opened his remarks with a revealing slip of the tongue: "When we go out to meet the enemy... I mean, the community..." Therein lies the problem; even the most sensitive law enforcement officer may find it difficult to separate his suspicions of the community from his suspicions of troublemakers that he fears may lie within the community but has been unable to identify. When the state acts preventively, this confusion is especially likely, because law enforcement officials don't know who or where the future troublemakers actually are.

How can the divide between the community and the police be bridged? Citizen-police councils are a good start. If they are undertaken in good faith, they may help demystify the community for the police, and vice versa. Constructive police-community partnerships of the type David Kennedy has advocated may also build trust. Better education of the police about the costs of illegitimate policing might increase police sensitivity to that concern. Similarly, better information sharing by the police to explain to the community what they are doing and why may help build trust. Community-based nongovernmental organizations may enable members of the community to express their concerns to the police more effectively.

But the problem is not just one of communication; it is also often one of practice. If the police are employing preventive coercive measures that sweep too broadly, or that appear to discriminate against particular communities, or that fail to treat community members with dignity and respect, the legitimacy of their efforts will be undermined. In this sense, effectiveness of prevention is linked inextricably to the normative justice of the preventive measures. A preventive measure that "works" in disrupting crime but is widely viewed in the community as unfair, unduly harsh, or discriminatory, will have significant counterproductive consequences that will compromise its preventive effectiveness.

Rights concerns are often identified as being in tension with law enforcement interests. The Fourth Amendment, for example, is typically described as balancing protections of privacy against interests in effective law enforcement. There are, to be sure, difficult tradeoffs to be made. But what is often lost in the language of tradeoffs is the extent to which rights concerns and security are mutually reinforcing. If preventive measures are carried out in ways that are consistent with rights concerns, they will gain legitimacy, which in turn will foster both law-abiding and law-enforcement-assisting behavior on the part of the citizenry.

\section{B. Resource Constraints}

Resource constraints are another informal limitation on coercive preventive measures. Law enforcement is always costly, but when it is employed to bring criminals to justice, there are measurable outcomes; a proven criminal is or is not held accountable for specific past acts. The effects of preventive measures are, by contrast, nearly always speculative. One can rarely know what might have happened if the preventive measures were not adopted. The mark of a successful preventive measure is that nothing happens. The mark of an unnecessary and wasteful preventive measure is the same. The United States has not had another major terrorist attack on its soil in the twelve years since 9/11, but it is impossible to say which of the many preventive initiatives undertaken in the interim can take credit for that fact. 
Prevention is expensive. Because we cannot predict where the next threat might arise, or what form it might take, preventive initiatives tend to sweep much more broadly than investigations of specific past or ongoing crimes designed to bring specific perpetrators to justice. As noted above, the United States is spending roughly $\$ 20$ million per suspected terrorist per year on preventive counterterrorism measures. At some point, that kind of expenditure is just unsustainable. ${ }^{48}$

Scarcity may become less of a constraint, however, as technological advances in computing make it cheaper to engage in mass surveillance. The fact that most of what we do these days leaves a digital trace, and that computers can easily access, collect, and mine that data in ways that were simply not possible before the digital age means that police are more likely to be tempted to employ dragnet measures. In the old days, the cost of dragnet surveillance was probably as much of a deterrent as constitutional doctrine. Today, as Edward Snowlden's revelations about NSA spying illustrate, the costs of dragnet surveillance have become much less significant, making the adoption of legal rules and strong norms all the more important.

\section{Accountability Mechanisms}

Accountability mechanisms might also help keep prevention in check. Too often, preventive measures are undertaken in secret, and little effort is made to account for their success or failure. When an investigation culminates in a criminal prosecution for a foiled terrorist act, of course, we see the results of preventive policing quite vividly. But that is the exception to the rule. When, for example, the New York Police Department engages in widespread stop-and-frisk practices, the FBI recruits informants and sends undercover agents into Muslim communities, immigration authorities call in foreign nationals from Arab and Muslim countries for "special registration," the Transportation Security Administration (TSA) places individuals on no-fly or secondary screening lists, the Treasury Department designates a suspected supporter of terrorism and freezes his assets, or the NSA collects detailed "metadata" on every American's phone use, the public often knows little or nothing about the cost and/or effectiveness of these programs. Most can and are undertaken without having to justify the action to a court, and many are undertaken on the basis of classified evidence. Little if any reporting, even in the aggregate, is done on the effectiveness of these measures.

More transparent reporting on such measures may create pressures to keep them in check. If the public knew, for example, how much "special registration" cost and whether any of the approximately 83,000 foreign nationals subject to "special registration" were ultimately convicted of a terrorist crime, that information might guide assessments of whether the program was worth it. If the TSA reported on the number of people subject to secondary screenings and the number of times secondary screenings revealed someone carrying a prohibited item on an airplane, that data might inform judgments about the accuracy and effectiveness of that program. The police generally do not publish the outcomes of stop-and-frisk practices, but data disclosed in connection with a class action lawsuit in New York City has revealed that over 700,000 persons were stopped in 2011

\footnotetext{
$\overline{48}$ William Stuntz and Dan Richman have argued that, for this reason, pretextual prosecutions are much less likely to be undertaken by state than federal prosecutors. Daniel Richman and William Stuntz, Al Capone's Revenge: An Essay on the Political Economy of Pretextual Policing, 105 Colum. L. Rev. 583 (2005). State and local police generally have limited resources and a specific jurisdiction, and must dedicate most of their limited resources to responding to serious crimes and bringing the perpetrators of such crimes to justice-for those crimes-within that jurisdiction. Id. at 600-605.
} 
alone, and that the tactic rarely resulted in the discovery of contraband or weapons. These facts, and the public debate they fostered, may already have led to a paring back of the program, according to the most recent statistics. ${ }^{49}$ What have been the results of the Treasury Department's asset-freezing program in terms of terror funds halted, and at what cost? What terrorist plots has the NSA's telephone metadata program helped to foil? ${ }^{50}$ What is the basis for the government's assertions that those it has targeted are in fact involved in terrorism? Again, if this information were made public, the public would be better equipped to assess whether these costly programs are worth it.

As noted above, one cannot ultimately measure in any precise way the effects of many preventive measures, because if nothing happens, one generally cannot know whether that was because nothing would have happened anyway, or because a preventive program deterred or prevented something bad from happening. But some assessments can be made. If, as Jules Lobel and I have shown, not one of the over 5,000 foreign nationals preventively detained in counter-terrorism initiatives after $9 / 11$, not one of the 8,000 young men from Arab and Muslim countries whom the FBI sought out for interviews after 9/11, and not one of the 83,000 persons called in for "special registration" by immigration authorities after 9/11 was ultimately convicted of a terrorist offense, it suggests that the net was cast too widely, and that a more targeted approach might have proved more effective-and less likely to generate resentment among Muslim communities. ${ }^{51}$ But these statistics are rarely if ever reported by the government. Watchdog groups and scholars do the best they can to fill the gaps, but the extent to which the programs and their implementation are classified make such assessments difficult. Requiring more robust and transparent reporting as a matter of law would be far preferable.

Without adequate accountability mechanisms, there are few incentives to cut back on preventive initiatives. Because assessments are often speculative, initiatives are often secret, and at its core the extent to which prevention works is often unknowable, those selling such programs are rarely challenged. Meanwhile, decision-makers fear being blamed after the fact for not taking every possible precaution. Fear drives spending, and promises of prevention are easy to make and difficult to disprove.

\section{Breadth}

The final informal or political check on preventive measures is a decidedly mixed blessing. The more sweeping a preventive measure is, the more likely it is that political checks will ensure that it respects citizens' rights. By contrast, the political process is unlikely to constrain more narrowly targeted preventive programs. As noted above, because of the difficulty of predicting the future, preventive initiatives often tend to sweep broadly. If they sweep broadly enough, they will implicate enough people's interests that the democratic process will register those concerns. Thus, security procedures at airports have been repeatedly revised and streamlined in response to objections about unfairness, undue burdens, and the like. These procedures apply to everyone, so we all have an interest in

\footnotetext{
49 El-Ghobashy and Saul, supra note 47; Center for Constitutional Rights, 2011 NYPD Stop-and-Frisk Statistics, supra note 44.

50 The NSA has been able to identify only one or perhaps two such cases. See Shaun Waterman, NSA chief's admission of misleading numbers adds to Obama administration blunders, Wash. Times, Oct. 2, 2013, available at http://www.washingtontimes.com/news/2013/oct/2/nsa-chief-figures-foiled-terror-plotsmisleading/?page=all.

51 See David Cole and Jules Lobel, Less Safe, Less Free: Why America Is Losing the War on Terror 107-109 (2008).
} 
ensuring that they are minimally invasive. That concern, for example, caused the TSA to adapt its screening technology recently to avoid the revealing images that its imaging machines initially created. Public outcry was sufficient to force a change.

Similarly, the few security proposals that generated legislative opposition in the immediate aftermath of 9/11 were those that implicated everyone's rights - the suggestion that the United States introduce a national identity card; the Terrorism Information Prevention System program, which was designed to recruit delivery employees and others to spy on homeowners and report suspicious activity; and the Total Information Awareness datamining program, in which the military proposed to mine all the electronic data available about all of us for patterns of terrorist activity. Each of these programs implicated everyone's rights, and sparked immediate opposition, leading Congress to prohibit any expenditure on them. ${ }^{52}$ Reactions to the NSA's phone data program in the summer and fall of 2013 reinforce the point. This program touches the rights of every American who uses a phone, and has consequently generated substantial protest.

By contrast, more targeted measures that do not implicate the rights of a broad swath of the public often generate little public opposition. American citizens and media expressed far more concern over the military detention of two U.S. citizens than over the detention of hundreds of foreign nationals in Afghanistan and in secret prisons around the globe. Americans showed much greater concern about the use of a drone to kill an American than their use to kill thousands of foreign nationals. And the NSA program focused on Americans has prompted far greater protest at home than the programs targeted at foreign nationals. As long as security measures could be defended on the ground that the government was sacrificing the rights of aliens, not citizens, they generated little opposition from Congress or the general public. ${ }^{53}$

This has both beneficial and pernicious effects. It creates a built-in brake on prevention, because the government knows its actions will be more difficult to sustain politically the more widely they apply. But it also encourages double standards that treat "them" differently from "us." And as long as the government adopts narrowly targeted prevention mechanisms that it can assure the general public it need not worry about applying to themselves, the majoritarian political process is unlikely to pose any real roadblocks.

\section{Conclusion}

Notwithstanding the ubiquity of preventive motives in ordinary criminal law enforcement, preventive coercion imposed without a specific criminal act poses distinct normative concerns. When the state acts on the basis of predictions, it must necessarily reduce the degree of certainty it demands before imposing coercion, because there is an inherent uncertainty about the future. To the extent that it restricts an individual's liberty based on fear of what she might do in the future, it disrespects her free will to choose to conform her actions to the law. The need to base predictions on generalizations makes selective enforcement a particular risk, as racial and ethnic profiling demonstrate. The absence of good metrics for prevention's success undermines the effectiveness of feedback data to check government excesses. And the inherent difference between visible false negatives and invisible false positives skews decision-making. These concerns should make us

\footnotetext{
52 David Cole, Enemy Aliens: Double Standards and Constitutional Freedoms in the War on Terrorism $72-74$ (2004).

53 Id.
} 
skeptical about preventive coercion. It unquestionably has a place in law enforcement, but its place must be carefully circumscribed.

In U.S. law, formal legal checks do impose some outer bounds on how far the state may go in depriving individuals of their liberty or property on preventive grounds. In theory, rights of free speech, free association, substantive and procedural due process, equal protection, limits on entrapment, and the right not to be penalized without a criminal trial constrain preventive measures. However, each of these constraints is itself limited in practice for various reasons, especially in times of fear where demands for prevention are at their highest.

The absence of robust legal constraints does not mean, however, that the government is entirely free, within the bounds of what courts will enforce, to impose preventive coercive measures. A number of informal, practical, and "soft law" constraints may in fact do much of the day-to-day work in confining the scope of preventive justice. If preventive measures are perceived as illegitimate, because they depart from the spirit of the constitutional and normative principles identified above, they will be less effective. Thus, police will have incentives to rein in their programs when they see the deleterious effects they are having. Preventive measures are costly, and resource limitations may play a moderating role in preventive justice as applied. Accountability mechanisms, rendering preventive initiatives and their results more transparent, may also promote a more modest preventive paradigm. And finally, to the extent that preventive measures sweep broadly, they are more likely to generate widespread democratic opposition.

In the end, then, it is critically important to recognize that preventive justice poses distinctive concerns. At the same time, in part because prevention is a legitimate goal and tactic in many settings, the formal legal limits on prevention are relatively modest, principally policing only the outer bounds of prevention. Most of the checks on preventive justice are likely to be the result of less formal, soft law concerns. And this means that we, as citizens, are ultimately the ones responsible for preventing the worst of prevention.

Acknowledgments I wish to thank Alec Walen for astute comments on a draft of this article, as well as the participants in a Robina Institute of Criminal Law and Criminal Justice symposium on preventive justice at the University of Minnesota Law School. 